Katharina Peterke

UDK 811.163.41'42:32

Univerzitet u Novom Sadu

Filozofski fakultet, doktorand

katarina.peterke@gmail.com
811.111'42:32

811.112.2'42:32

DOI: 10.19090/zjik.2019.53-71

originalni naučni rad

\title{
A CROSS-CULTURAL ANALYSIS OF THE CONCEPTUAL METAPHORS OF BREXIT: EVIDENCE FROM ENGLISH, GERMAN AND SERBIAN ${ }^{1}$
}

\begin{abstract}
Conceptual metaphor has long been recognised to reflect our human emotional and cognitive world. Its ability to evoke emotional response and influence attitudes makes conceptual metaphor ideal for the use in political content. A recent controversial political issue is Brexit. The objective of the present paper is to compare the metaphor use in the British Brexit discourse to the metaphor use in the media of other language areas. The chosen languages are German, as language of another EU country and Serbian as the language of a country that is not in the European Union and is therefore not directly affected by Brexit so far. The data is taken from reliable online media sources of Britain, Germany and Serbia. Metaphors have been identified using the MIPVU procedure in 20 articles for each language. In a total of 259 metaphors, the three languages show interesting differences in the use of conceptual metaphors in the context of Brexit.
\end{abstract}

Key words: conceptual metaphor, Brexit, media, political content, language areas.

\section{INTRODUCTION}

Conceptual metaphor has long been recognised as a cognitive device reflecting our reality, the human mindset and a culture's mentality and influencing our perception of the world (Lakoff \& Johnson, 2003: 3). It is not understood as a stylistic device anymore, but as a matter of thought. The following paper uses the term metaphor in this sense.

${ }^{1}$ The original version of this paper was written for the doctoral course EnglishSerbian Cognitive Semantics under the supervision of Dr Sonja FilipovićKovačević. 
Governing our mind via conceptual structures, metaphor is knowingly and effectively used in the field of politics. Politicians use powerful cognitive images to make their contents more relatable, to appeal to the audience's emotions and influence their perception and attitude.

This study deals with Brexit, the withdrawal of the UK from the European Union, as a controversial issue with internationally far-reaching consequences. The change in political affairs affects governments and the regulations of the EU and has considerable consequences for individuals worldwide. Many fear the negative effects the isolation of the UK might have on the academic, touristic, economic, medical and other fields. Being an emotionally charged topic, Brexit discourse in the media is highly metaphorical. In the past, Brexit-related metaphor use was not much above the usual level and it comprised mainly already known conceptualisations like STATE IS A BODY, STATE IS A FAMILY WITH MARRIED PARENTS (Musolff, 2004: 14). Metaphor use was significantly increased recently, when Brexit became a reality and gained momentum. It has become so excessive that Landale (2017) suggested politicians and the media to stop using metaphors for Brexit and call it by its name instead.

The present study sets out to investigate conceptual metaphors used in the media in 2018, the year of decisions on the transition period, the UK's economic relationship with the EU and the legal conditions of Brexit, in three languages: English, as language of the directly concerned country; German, the language of an EU country affected by the situation in several ways; and Serbian, the language of a country that is not truly affected by Brexit so far. The aim is to observe and interpret the differences in conceptual metaphor use in the media of the three countries in the light of affectedness by the political situation of Brexit. The specific concepts (MARRIAGE, JOURNEY, GAME, BODY, DRAMA and WAR) used in the three languages in the analysed material from 2018 are examined via numerous lexical realisations.

\section{THEORETICAL BACKGROUND}

With a Conceptual Metaphor like POLITICS IS A GAME, the human mind structures general and abstract concepts (POLITICS, target domain) in terms of more concrete concepts (GAME, source domain) (Lakoff \& 
Johnson, 2003: 4). Shared properties of the concepts like having winners and losers (of the game or the political conflict) and rules (or laws and regulations) make the meaning of the abstract target domain more graspable. The manifestations of conceptual metaphors are linguistic metaphors like "Politicians are gambling with the lives of thousands" or "Their party won". Metaphor highlights only certain aspects of a domain/concept, while hiding others (Lakoff \& Johnson, 2003: 10). In this example, power-related issues, serious conflicts and warfare are hidden.

Carefully chosen cognitive images underlying conceptual metaphors influence the audience's beliefs about a topic (Gibbs, Leggitt, Turner, 2002: 129), while they "stir emotions and bridge the gap between the logical and the emotional" (Charteris-Black, 2006: 565). When, for example, the US Secretary of Energy Rick Perry calls president Trump's candidacy a "cancer on conservatism" (Blake, 2017), the intention of evoking a negative emotional response in the audience by conceptualising an UNSUITABLE CANDIDATE as an ILLNESS is obvious. A study by Gibbs et al. (2002: 138) substantiated the benefits of using metaphor in political speeches, revealing that listeners show a more intense emotional response to metaphorical expressions than to literal statements.

Metaphoric scenarios are even more effective than "simple" conceptual metaphors. While a domain evokes a specific cognitive image, scenarios represent a whole scene and new context. According to Musolff (2006: 23) they serve as mini-narratives carrying an evaluative stance. A popular "scenario" metaphor is STATE IS A FAMILY WITH MARRIED PARENTS (Musolff, 2004: 14). We all know the whole context of being part of a family, desiring to keep the family (countries) together and protect it, the joy, when a new child is born or adopted (e.g. EU member state). This makes a political issue highly relatable and emotional. In the Brexit context, the MARRIAGE scenario is frequently used, producing a clearly gendered discourse character: Britain is the unfaithful wife, while the EU is the aggrieved husband (Đurović \& Silaški, 2018: 3). The receiver of the message will likely feel sympathy towards the betrayed, which shows the manipulative power of metaphor.

Concerning the audience's emotional and cognitive response, novel metaphors are particularly effective (Gibbs et al. 2002: 137). Target and 
source domain in novel metaphors share much less properties than in conventional metaphors, which coincides with a higher degree of metaphoricity (Hanks, 2006: 5). The cake philosophy in the Brexit discourse, for example, is based on the conceptualisation POLITICAL IDEAS ARE FOOD where source and target domain share a very small number of properties. It is used in the frequently used phrase "You cannot have your cake and eat it", alluding to Britain's attempt to keep the good relationship with the $\mathrm{EU}$ (have your cake), while leaving the EU (eat the cake). In the conventional metaphor They won the election - POLITICS IS A GAME source and target domain share more properties, which reduces the metaphoricity.

Several studies conducted after the 2016 referendum have underpinned the objectives of the present study. Morozova (2017: 273) confirms the reflection of an author's attitude in the variation of metaphor. Monomodal verbal metaphors of Brexit tend to impose a particular ideological position upon the addressee by appealing to his rational and multimodal verbal metaphors to his emotional sphere (Ibid).

Daddow (2019: 5) recognises a Eurosceptic twist in Britain's foreign policy narrative using expressions like EU prison to evoke a negative attitude towards the EU in citizens.

Đurović and Silaški (2018) recognise the MARRIAGE and DIVORCE metaphors of the MARRIED PARTNER scenario as essential linguistic means in the Brexit discourse. Their findings show a great cognitive potential of these metaphors as "powerful markers of national identities and devices for shaping conceptualisations of the given reality" (Ibid.: 19).

Tapper (2019) explains why conceptual metaphors used in Brexit discourse are mostly conventional: creative metaphors hold the risk of being recognised as manipulative means by the audience.

Based on these findings, the present study sets out to investigate cross-cultural metaphor use in Brexit discourse and also looks at potential connections with political involvement of the respective countries of text origin. 


\section{CORPUS AND METHODOLOGY}

The present analysis is based on a corpus of 20 online news articles for each language. The length of the German and English articles is comparable; they contain around 1000 words each. The Serbian texts found on the topic in online sources for the year 2018 are somewhat shorter, around 500 words each (which results in a correspondingly lower number of metaphors). Comments and headlines were not taken into consideration. To ensure a comparable level of quality, only prestigious online news sources have been looked at. For the English language data, these were $B B C$ news, The Independent, and The Guardian. The German news articles looked at stemmed from Der Tagesspiegel, Die Zeit, Der Spiegel and Die Welt. The Serbian data sources were NIN, Danas online and Politika online. In order to avoid a flawed analysis due to adopted metaphors, attention was paid that the articles were not translated from other sources, which is usually indicated at the bottom of the page. The articles were all written and published in 2018 as the year of decisions on the transition phase, the legal elaboration of Brexit and negotiations concerning the EU's future relationship with Britain. The issue gained momentum during that year and metaphors used in the context were expected to be frequent and characteristic. The texts were found performing an online search with the key items Brexit 2018 and Bregzit 2018. Then, comments, speeches and texts containing a large number of quotes were excluded from the material.

Metaphors were identified following the MIPVU procedure comparing the contextual and basic meaning of linguistic units (Steen et al., 2010: 25-26). The total number of metaphors found was 259, 115 of which are contained in the collected German texts, 91 instances appear in the English texts and 53 metaphors were found in the Serbian texts. The metaphors were then classified according to their underlying conceptualisations in all three languages. Special attention was paid to the difference in the linguistic metaphors the different languages produce on the basis of the respective conceptualisation and the differences in the frequency of certain conceptualisations. 


\section{ANALYSIS}

Due to the heated discussions about Brexit in 2018, a high productivity in conceptual metaphors is to be expected in the media. There is also an expected difference in the concepts used in dependency of how affected the language area and its people are by the political consequences of Britain's decision.

\subsection{The metaphoric conceptualisation of Brexit in Great Britain}

Of the 91 metaphors analysed from the English material, 23 are JOURNEY metaphors. JOURNEY represents a rather conventional source concept in political discourse and a highly relatable metaphor scenario (Silaški \& Đurović, 2019: 3). In the context of Brexit, the conceptualisation the metaphors in the data stem from is BREXIT IS A JOURNEY (25.3\%):

(1) a) "the public could opt for a different path" (The Independent, $01 / 01 / 2018)$

b) "before we depart from the world's largest trading block" (The

Guardian, 22/12/2018)

Besides these rather conventional instances describing the political development of Brexit in the picturesque terms of travel, there are some unconventional realisations of the abovementioned conceptualisation like:

c) "how much of his programme was bring-backery" (The Independent, 02/06/2018),

emphasising the nostalgic orientation of politicians who support Brexit. This metaphor clearly expresses the failure of Britain to ensure a progressive political development returning to the political past instead.

With $18.7 \%$ of the total of metaphors, the conceptual metaphor THE POLITICAL SITUATION IS A DRAMA is among the most frequently used in the data. Examples of the linguistic realisations are:

a) "In the next Act of Brexit" (The Independent, 01/01/2018) 
b) “worst-case, no-deal scenario" (The Guardian, 28/11/2018)

The DRAMA metaphor implies the inability of the public to change the course of events - they can only be spectators of the staged "play". The ending of the play is not yet clear and the public waits to see the further development of the plot in the next Acts.

There are slightly less instances of the conventional conceptual metaphor of MARRIED PARTNERS that depicts the relationship between two states in a more relatable manner (15.4\%).

a) "It was a story of break-up and betrayal" (BBC, 24/05/2018)

b) "The UK and EU have provisionally agreed on the three 'divorce' issues” (BBC, 21/06/2018)

As the relationship between Britain and the EU is falling apart, the predominant image of divorce and break-up is no surprise. Especially the term betrayal holds polarising potential - people are prone to identify with one of the partners in ending relationships. As mentioned earlier, the MARRIED PARTNERS metaphor represents not only a concept, but a whole narrative everyone in the audience can relate to, which makes it especially powerful.

Another frequently used concept is WAR (13.2\%), emphasising the severity of the situation and the force with which the political parties try to get their way:

a) "no prime minister in history (...) has fought such a brutal personal war on two fronts" (The Independent, 24/12/2018)

Opposed to the severity of the WAR metaphor, the GAME metaphor (used 10 times, which makes $11 \%$ of the total of metaphors) presents the British government as gambler risking the future of the people, or as player performing irresponsible or incomprehensible moves:

a) "...the leave campaign was characterised by foul play." (The Guardian, 23/05/2018)

b) “...ministers are gambling with the security..." (Ibid.) 
The foul play holds polarising potential as it evokes a negative attitude towards politicians supporting the leave campaign.

An interesting but less frequent conceptual metaphor used in the British Brexit discourse is the ILLNESS metaphor $(6.7 \%$ of the total number of metaphors). The conceptualisation of STATE IS A BODY is one of the most conventional conceptual metaphors in the political context. In the Brexit discourse, the linguistic metaphors derived from this conceptualisation are referring to illness and decay. They can have highly emotional connotations and be rather novel, even without novel conceptualisation:

a) "Gordon Brown warns of Brexit 'Paralysis" (BBC, $05 / 06 / 2018)$

b) "Britain could be 'paralyzed' for years because Westminster parties have not 'woken up"” (Ibid.)

c) “...the 'chronic uncertainty' surrounding Brexit talks..." (BBC, $08 / 06 / 2018)$

Implying a decaying and handicapped state "chronically" being in a negative condition, these metaphors cause a negative attitude towards the government in the readers.

With Brexit being an emotionally charged issue, the frequent use of novel metaphors was expected. Analysis of the present data has resulted in the finding that there is no exceptionally high productivity in novel metaphors. There are some instances of COMPUTER metaphors (plugged firmly into the Brexit matrix, The Independent, 13/11/2018) and BUILDING metaphors (keeps the door open to all options, Ibid.), but both are represented with only $3.3 \%$ and might just reflect the personal style of the author. The same is valid for the rare, but interesting FAIRYTALE metaphor (4.4\%) presenting Brexit as a surreal phenomenon that cannot be taken serious (described her previous customs proposal as "magical thinking", The Guardian, 09/07/2018). 


\subsection{German Brexit metaphors}

Out of a total of 115 metaphors, the conceptual metaphor BREXIT IS A JOURNEY is the most frequent in German as well as in English (26\%).

a) „Niemand scheint die politische Macht zu haben, um die Blockade aufzulösen.” (Die Zeit, 17/12/2018)

[Nobody seems to have the power to take down the blockade.]

b) „...bremst die Brexit-Unsicherheit schon jetzt die britische Wirtschaft spürbar" (Die Zeit, 19/12/2018)

[The uncertainty of Brexit already slows down the British economy.]

In German, the JOURNEY is impeded by "blockades" and brakes "slowing down" the traveller (in this case the British economy). Problems and barriers in the future political and economic situation of Britain are implied. There is no element of nostalgia and returning to the past as in the English data.

Interestingly, there is a much higher percentage of GAME metaphors in the analysed German than in the English texts (20.9\% of the total number of metaphors). The concept reflects the critical attitude the German public and media have towards the political development in Britain. They are watching the development with disbelief and see British politicians as "gambling" on the future of their people:

(8) a) „Ganz nach britischem Geschmack und eigenen Regeln” (Der Spiegel, 17/12/2018)

[Completely according to British taste and independent rules.]

b) „Sie hat immer weniger Optionen - und setzt nun alles auf eine Karte.” (Die Welt, 10/12/2018)

[She has a decreasing number of options - and goes for broke now]

Gambling on the future of people is a metaphor appearing in English and in German. However, the concept appears much more 
frequently in the German media, which enforces the implicit expression of the irresponsibility of Britain's decisions. The rules of the game mentioned in the German data emphasise the stubbornness of Britain in applying only their own rules.

The MARRIAGE and DRAMA metaphors are used slightly less frequently in the German than in the analysed English data. $13.9 \%$ of the total of metaphors are MARRIAGE metaphors in the German texts. Interestingly, the data contains only the more neutral terms of Scheidung (divorce of Britain and the EU) and Partnerschaft (partnership), while English texts show a frequent use of the polarising term betrayal.

a) „Neun Monate bleiben der Regierung noch, um die Scheidung zu vollziehen.” (Der Spiegel, 16/06/2018)

[The government has nine more months to put the divorce into effect.]

b) „....streben die EU und Großbritannien eine „ehrgeizige“ und „tiefe“ Partnerschaft an.” (Spiegel online, 25/11/2018)

[...the EU and Great Britain strive to establish an "ambitious" and “deep" partnership.]

The DRAMA metaphor is used in a similar way as in the English data, mostly mentioning the different scenarios people should be prepared for:

(10) a) „Im Kabinett werden zwei Szenarien durchgespielt.“ (Der Spiegel, 15/12/2018)

[Two scenarios are simulated in the cabinet.]

However, the concept appears much less frequently (13\% of the total number of metaphors) than in the English texts and does not produce a variety of linguistic metaphors.

Besides the metaphors of illness present in the English data as well, the BODY metaphor shows interesting instances of surgery and amputation in the German data. It appears more frequently than in the English texts $(11.3 \%)$ : 
(11) a) „Er ist eine Amputation, eine chirurgische Trennung...” (Die Zeit, 18/12/2018)

[It is an amputation, a surgical separation...]

This metaphor implies a complex process and severe state of illness before a part of the body is taken away, which symbolises the handicapped state Britain will be in after losing the EU.

The WAR metaphor is represented with only $10.4 \%$ in the German data. The respective linguistic metaphors are Kampf (Die Zeit, 18/12/2018), meaning mostly the fight of Theresa May for the achievement of her political goal of Brexit and Schlacht (Die Welt, 25/11/2018) denoting the battle between Britain and the EU concerning the conditions and outcomes of Brexit. Thus, the tone of the WAR metaphors coincides with the English instances.

Other interesting but only sporadically represented German Brexit metaphors from the observed texts originate from the concepts FAIRYTALE (e.g. märchenhafte Vision - fairytale-like vision), DANCE and BUILDING (e.g. sie wollen raus - they want to exit), all represented with $1.7 \%$ of the total number of metaphors. Due to their scarcity, they might just be personal stylistic choices of the author. Nevertheless, some of them are noteworthy, especially the example Man braucht zwei, um einen anständigen Tango hinzulegen (Der Spiegel, 19/12/2018) meaning You need two to dance a decent Tango. The choice of Tango as passionate and powerful dance with romantic elements and the lack of one partner for dancing it expresses the formerly close relationship of Britain and the EU, where now one partner is left behind to "dance alone". Concerning the emotional and cognitive response, this metaphor might be one of the most effective out of the collected data due to its novelty (Gibbs et al. 2002: 137).

\subsection{Serbian Brexit metaphors}

A recent study has shown that Serbian newspapers (Blic and Politika) publish mostly factual reports about Brexit, without much analysis and linguistic sensitivity (Milinkov \& Šinković, 2016: 79). Indeed, there seems to be less variation in Serbian Brexit metaphors, which in the 
framework of this study might be due to the reduced length of the observed online articles. The articles contained a total of 53 metaphors.

While the JOURNEY metaphor shows the highest abundance in the English and German data, the most frequent concept in the Serbian data is MARRIED PARTNERS (20.7\% of the total number of metaphors):

a) ,...produžetak takozvanog tranzicionog perioda i nakon 2020, za kada je bio planiran 'raskid'." (Danas, 24/10/2018)

[...prolongation of the so-called transition period until after 2020, when the 'break-up' was scheduled.]

b) „...kakvi će biti budući odnosi dve strane nakon Bregzita...” (Danas, 26/11/2018)

[...what the future relationships between the two sides will be like after Brexit...]

c) „...ono što se trenutno dešava između Londona i Brisela plastično se može uporediti sa formalnim razlazom supružnika..." (Politika online, 10/07/2018)

[...what is happening between London and Brussels at the moment can vividly be compared to the formal separation of a married couple...]

As mentioned earlier, the MARRIED PARTNERS and RELATIONSHIP scenarios hold a high manipulative potential (Đurović \& Silaški, 2018: 3), especially when they are used in combination with betrayal, which causes a negative attitude towards the betraying "partner" in the audience. The Serbian data shows mostly instances of break-up, separation and relationship. The end of the close relationship between Britain and the EU is expressed, but the partners are on eye level, the audience is not manipulated into a negative attitude towards one or the other by the use of metaphors like betrayal.

In the Serbian data, the WAR metaphor appears with a high frequency (17\% of the total number of metaphors), for example:

a) „...premijerka ostala ranjena posle borbe.” (Danas online, $13 / 12 / 2018)$ 
[...the prime minister was left wounded after the fight.]

Like in the English and German data, this metaphor emphasises the seriousness of the situation.

The GAME metaphor is the third most represented metaphor in the Serbian data (15\%). As in the German and English data, the representations are referring to gambling games:

a) „... London igra na kartu polurazlaza...” (Politika online $10 / 07 / 2018)$

\section{[...London bets on a semi-separation...]}

The JOURNEY, DRAMA and BODY metaphors are all represented with only 9.4\%. The respective linguistic metaphors are similar to English and German instances, but especially the JOURNEY metaphor is much less frequent. The linguistic realisations of these less frequently used metaphors in the Serbian data correspond to the linguistic metaphors in the German and English data - kočnice (brakes), koraci (steps) and similar for JOURNEY, scenario for DRAMA and metaphors of illness and treatments for BODY, like dijagnozu (diagnosis), so na ranu (salt in the wound), terapijom (through therapy). Even if less represented and thus probably rather the style of the respective author, there are interesting instances of FAIRYTALE and TRADE metaphors in the Serbian data. Political arguments are presented as trade goods in examples like nije imala argumente koje bi mogla da proda (She didn't have any arguments she could sell, Danas online, 23/11/2018). FAIRYTALE metaphors like ko vidi jednoroga zavezanih očiju (who sees unicorns with bandaged eyes, Danas online, 23/11/2018) emphasise that the actions of the government cannot be taken seriously.

\section{CONCLUSION}

The analysis of the English, German and Serbian data obtained from 20 articles per language show moderate, but interesting differences in the metaphor use in Brexit context in the online media of the three language areas. 
Of the 91 English and 115 German metaphors, over 25\% are JOURNEY metaphors, while they represent only $9.4 \%$ of the Serbian data. An interesting difference between the English and German JOURNEY metaphors is the linguistic realisation of bring-backery and implications of looking backward in English as opposed to brakes (bremsen) and obstacles (Blockade) in German. In the German data, the journey is directed forward, impeded by political decisions in the Brexit context causing problems in the country. The British media presents politicians supporting Brexit as nostalgic and oriented towards the past. The Serbian metaphors are compliant with the German examples, describing a journey that is slowed down by brakes, meaning the unfavorable British decisions.

The most frequently used metaphor in the Serbian data is the MARRIED PARTNERS metaphor with 20.7\%. In the English and German data, the MARRIED PARTNERS metaphor holds the third place in frequency, constituting $15.4 \%$ of the observed English and $13.9 \%$ of the observed German metaphors. This conceptualisation is interesting, as in the analysed data it shows a gradation in accordance with the political affectedness of the countries of text origin. The Serbian and German MARRIAGE metaphors are characterised by a rather neutral tone (relationship, divorce, married couple, ...). Nevertheless, there is a slight difference in the frequent use of divorce in German as opposed to the formal separation in Serbian. The divorce is a legal process after which the marriage is formally ended, while the partners can remain legally married in case of a separation. The end of the relationship between Britain and the EU is presented more definite and severe in the German than in the Serbian data. The data from the British media uses the polarising metaphor betrayal, where the betraying partner causes a negative attitude in the audience. Although based on the same conceptualisation, the polarising potential of the metaphors used here seems to decrease in correspondence with the decrease in the political involvement of the countries.

DRAMA with scenarios as mainly used linguistic realisation is the second most frequent concept in the English data (18.7\%), while its frequency is significantly reduced in the German (13\%) and Serbian (9.4\%) data. In the English texts, the Acts of Brexit and scenarios emphasise the situation of the people who can only sit and watch the "Brexit play", hoping for a decent ending. The linguistic realisations of the DRAMA metaphor in 66 
German and Serbian are used in a similar sense as in English texts, but they are limited to scenarios in the present data.

The second most frequent metaphor in the German data is the GAME metaphor with $20.9 \%$. With $15 \%$ in the Serbian and only $11 \%$ in the English data, this metaphor shows the highest frequency in the German data. All three languages use this metaphor mainly in the context of gambling. The metaphors emphasise the irresponsibility of the British government in metaphorically expressing the risks the government takes concerning the future of their people. Again, it is the English data containing the most negative GAME metaphor: the politicians are accused of foul play in the leave campaign. The English metaphor holds the most polarising potential and causes a negative attitude towards the parties supporting Brexit in the audience.

The WAR metaphor shows a higher frequency in the Serbian (17\%) than in the German (10.4\%) and English (13.2\%) data. However, the linguistic realisations with battle and fight are comparable between all three languages and emphasise the seriousness of the situation and the violence with which the discussions are led.

The less frequently used metaphors like FAIRYTALE, BUILDING and BODY show a similar frequency in all three languages, as well as similar linguistic realisations. The magical thinking and similar FAIRYTALE metaphors express the attitude that the British government cannot be taken serious with its idea of Brexit. BUILDING metaphors present the EU as a building Britain wants to exit. BODY metaphors are characterised by illness and decay in this context, emphasising the negative condition of Britain as well as the future handicap after ending the close relationship with the EU.

All in all, it can be concluded that the analysed data shows interesting differences in the frequency of certain metaphorical concepts used in the analysed British, German and Serbian texts on Brexit, as well as differences in the respective linguistic realisations. An assumed influence on these differences is the different degree of political involvement, i.e. affectedness of the language areas. Especially the higher abundance of polarising metaphors in the English than in the German and Serbian data supports this assumption. However, the present study is a small-scale study, 
which would have to be repeated on a larger sample in order to prove the tendency generally valid.

\section{REFERENCES}

Blake, Aaron. 2017, The many metaphors for Donald Trump. https://www.washingtonpost.com/news/the-fix/wp/2017/05/07/the-manymetaphors-that-describe-donald-trump/?noredirect=on\&utm _ term $=.9220 \mathrm{~d} 5 \mathrm{~b} 27057$ (29.05.2018).

Charteris-Black, Jonathan. 2006. Britain as a Container: Immigration Metaphors in the 2005 Election Campaign. Discourse \& Society 17(6): 563-582.

Charteris-Black, Jonathan. 2011. Politicians and Rhetoric: The Persuasive Power of Metaphor. $2^{\text {nd }}$ edition. Hampshire: Palgrave Macmillan.

Daddow, Oliver. 2019. Global Britain ${ }^{\mathrm{TM}}$ : The Discursive Construction of Britain's Post-Brexit World Role. Global Affairs 5(1): 5-22. DOI: 10.1080/23340460.2019.1599297.

Đurović, Tatjana; Silaški, Nadežda. 2018. The End of a Long and Fraught Marriage: Metaphorical Images Structuring the Brexit Discourse. Metaphor and the Social World 8(1): 25-39.

Gibbs, Raymond W. jr. et al. 2002. What's Special about Figurative Language in Emotional Communication? In: Fussell, S.R. ed. 2002. The Verbal Communication of Emotions: Interdisciplinary Perspectives. Mahwah: Lawrence Erlbaum Associates Inc.: 125-150.

Hanks, Patrick. 2006. Metaphoricity is Gradable. In Stefanowitsch, A. and Gries, S. eds. 2006. Corpora in Cognitive Linguistics Vol. 1: Metaphor and Metonymy. Berlin: Mouton de Gruyter: 17-35.

Kaiser, Charles. 2016. Why Brexit is the biggest step backward since World War II. https://edition.cnn.com/2016/06/25/opinions/brexit-stepbackward-charles-kaiser/index.html (01.06.2018).

Kennelly, Larissa. 2018. Brexit: the top five clichés [Video file]. www.bbc.com/news/av/uk-43573752/brexit-the-top-five-cliches (28.05.2018).

Kielinger, Thomas. 2016. Was Sie wissen müssen, um die Briten zu verstehen. https://www.welt.de/wirtschaft/article151708663/WasSie-wissen-muessen-um-die-Briten-zu-verstehen.html (01.06.2018). 
Lakoff, George; Johnson, Mark. 2003. Metaphors We Live By. $2^{\text {nd }}$ edition. Chicago: The University of Chicago Press.

Landale, James. 2017. Brexit means what? Time for the metaphors to stop. https://www.bbc.com/news/uk-politics-40726215 (28.05.2018).

Mercer, Phil. 2018. New Zealand happy to forget the UK's 'betrayal'. https://www.bbc.com/news/business-44210833 (02.06.2018).

Milinkov, Smiljana; Šinković, Norbert. 2016. "Izveštavanje Blica i Politike o Bregzitu - identitet za druge u medijskom diskursu u Srbiji". Communication and Media 11(37): 63-83.

Mišić, Milan. 2016. Bregzit - svuda oko nas.

http://www.politika.rs/sr/clanak/357861/Bregzit-svuda-oko-nas (02.06.2018)

Morozova, Olena. 2017. Monomodal and multimodal instantiations of conceptual metaphors of Brexit. Lege Artis: Language yesterday, today, tomorrow 2(2): 250-283.

Musolff, Andreas. 2004. Metaphor and Political Discourse: Analogical Reasoning in Debates about Europe. Hampshire: Palgrave Macmillan.

Musolff, Andreas. 2006. Metaphor Scenarios in Public Discourse. Metaphor and Symbol 21(1): 23-38.

Musolff, Andreas. 2017. Truths, lies and figurative scenarios: Metaphors at the heart of Brexit. Journal of Language and Politics 16(5): 641657.

Ortony, Andrew. 1979. Beyond Literal Similarity. Psychological Review 86(3): 161-180.

Pham, Khue. 2017. Plötzlich heimatlos. https://www.zeit.de/politik/ausland/2017-03/brexit-grossbritannienremain-waehler (30.05.2018).

Rentoul, John. 2018. Theresa May and Jeremy Corbyn are both backwardlooking politicians - whatever happened to the future?

https://www.independent.co.uk/voices/nostalgia-better-life-growing-uptheresa-may-jeremy-corbyn-a8380491.html (05.06.2018).

Schindler, Jörg. 2017. Ex-Premier Tony Blair zum Brexit: 'Dann sind wir zweite Liga'. http://www.spiegel.de/politik/ausland/tony-blairwarnt-briten-im-interview-vor-brexit-folgen-a-1145373.html (02.06.2018).

Schindler, Jörg. 2018, June. Das Illusionstheater. Der Spiegel 25: 80-81. 
Segalov, Michael. 2018. Want a second Brexit referendum? Then stop talking about it. https://www.theguardian.com/commentisfree/2018/ may/23/second-brexit-referendum-attitudes-labour (01.06.2018).

Silaški, Nadežda; Đurović, Tatjana. 2019. The JOURNEY metaphor in Brexitrelated political cartoons. Discourse, Context and Media 31, 100318.

Soros, Džordž. 2017. Raspršene nade Britanaca o Bregzitu. https://www.danas.rs/svet/rasprsene-nade-britanaca-o-bregzitu/ (02.06.2018).

Steen, Gerard et al. 2010. A Method for Linguistic Metaphor Identification. From MIP to MIPVU. Amsterdam: John Benjamins.

Tapper, James. 2019. The many metaphors of Brexit. JSTOR Daily. https://daily.jstor.org/many-metaphors-brexit/ (10.08.2019).

Vukotić, Dragan. 2016. Bregzit - demokratija ili demagogija. http://www.politika.rs/sr/clanak/358402/Medunarodnipregled/Bregzit-demokratija-ili-demagogija (28.05.2018).

Ziedler, Christopher. 2016. Britisches Europa.

https://www.tagesspiegel.de/meinung/eu-und-grossbritannien-britischeseuropa/12911706.html (28.05.2018).

Katharina Peterke

MEĐUKULTURALNA ANALIZA KONCEPTUALNIH METAFORA BREGZITA: PRIMERI IZ ENGLESKOG, NEMAČKOG I SRPSKOG JEZIKA

Rezime

Metafore se od pre nekoliko decenija više ne gledaju kao jezičko nego kao kognitivno sredstvo u kom se ogleda mentalitet i pogledi na svet (Lejkof \& Džonson, 2003: 3). Kao takvo mogu da utiču na našu percepciju i emocije (Gibs et al., 2002: 129), što je posebno važno u političkom diskursu. Ovo istraživanje se bavi konceptualnim metaforama u kontekstu Bregzita: napuštanja EU od strane Velike Britanije.

Posmatra se upotreba konceptualnih metafora u medijskom diskursu u 2018. godini u kojoj je održan veliki broj pregovora o uslovima izlaska Velike Britanje iz Evropske unije. Izvršena je analiza medijskih onlajn izvora Velike Britanje kao aktera ( $B B C$ news, The Independent, The Guardian), Nemačke kao druge EU članice (Der Tagesspiegel, Der Spiegel, Die Zeit, Die Welt) i Srbije kao države koja 
nije član EU i dosad nije direktno pogođena razvojem situacije (NIN, Danas online, Politika online). Cilj istraživanja je poređenje metafora korišćenih u medijskom diskursu ove tri kulturološki i politički različite države. Metafore iz 20 članaka za svaki jezik su identifikovane MIPVU procedurom, a klasifikovane prema konceptima.

Analiza je pokazala da su uglavnom korišćene iste konceptualizacije u sva tri jezika: DRŽAVE SU BRAČNI DRUGOVI, BREGZIT JE PUTOVANJE, POLITIKA JE IGRA, DRŽAVA JE TELO. Razlika u korišćenju navedenih konceptualizacija je u različitoj frekventnosti koncepata i u različitim jezičkim metaforama koje proizilaze iz tih koncepata. U prikupljenim engleskim i nemačkim tekstovima primećuje se povećana upotreba metafora koje imaju potencijal za polarizaciju što ukazuje na njihovu veću pogođenost političkim razvojem u odnosu na srpsko govorno područje.

Ključne reči: konceptualna metafora, politički diskurs, Bregzit, konceptualizacija. 